\title{
In vitro tests of suitability of bacteriocin-producing lactic acid bacteria, as potential biopreservation cultures in vacuum-packaged cold-smoked salmon
}

\author{
Elisabetta Tomé ${ }^{\text {a,b }}$, Vera L. Pereira ${ }^{\text {a }}$, Carla I. Lopes ${ }^{\text {a }}$, Paul A. Gibbs ${ }^{\text {c }}$, Paula C. Teixeira ${ }^{\text {a,* }}$ \\ ${ }^{a}$ Escola Superior de Biotecnologia, Universidade Católica Portuguesa, R. Dr. António Bernardino de Almeida, 4200-072 Porto, Portugal \\ ${ }^{\mathrm{b}}$ Instituto de Ciencias y Tecnología de Alimentos, Escuela de Biología, Universidad Central de Venezuela, Apartado 47.097 - Caracas 1041 A, Venezuela \\ ${ }^{\mathrm{c}}$ Leatherhead Food International, Surrey, UK
}

Keywords: Cold-smoked fish; Salmon; Bacteriocins; Listeria; Enterococcus; Lactobacillus; Pediococcus

\begin{abstract}
The objectives of this study were to ascertain the in vitro potential of nine bacteriocin-producing lactic acid bacteria (LAB) strains, isolated from vacuum-packaged cold-smoked salmon (CSS), for possible use as biopreservative cultures against Listeria monocytogenes. The antilisterial activity of cultures' supernatants was assessed at $0.5 \%, 3.0 \%$ and $5.0 \% \mathrm{w} / \mathrm{v}$ of salt, at $5{ }^{\circ} \mathrm{C}, 10{ }^{\circ} \mathrm{C}$ and $25{ }^{\circ} \mathrm{C}$ both in aerobic and anaerobic atmospheres, simulating the conditions pertaining in vacuum-packaged CSS. The kinetics of growth, bacteriocin biosynthesis, the minimum inhibitory concentrations (MICs) of ten antibiotics, histamine and tyramine production of LAB strains, were determined jointly with the haemolytic activity for the enterococci. Only five strains were able to secrete active bacteriocins into the culture medium, at high salt concentrations and low temperatures, both in aerobic and anaerobic atmospheres. Enterococci showed neither haemolyt ic activity nor vancomycin resistance. The production of histamine was not observed for any of the bacteriocin-producing strains.
\end{abstract}

\section{Introduction}

The consumer-led demand for more natural food products has also provided an increased interest in food-grade preservatives of biological origin. Some food-borne pathogenic bacteria, such as Listeria monocytogenes, can survive in lightly preserved food, stored at refrigeration temperatures, such as cold-smoked salmon (CSS), despite the various intrinsic and extrinsic preservation hurdles they encounter, and may pose a health risk to consumers (Henitz \& Johnson, 1998). In this respect, special interest has been focused on bacteriocins produced by lactic acid bacteria (LAB). These are ribosomally synthesized pep-

\footnotetext{
* Corresponding author. Tel.: +351 22 5580001; fax: +351 225090351. E-mail address: paula@esb.ucp.pt (P.C. Teixeira).
}

tides or proteins, with a narrow to wide antibacterial spectrum against Gram-positive bacteria, mainly closely related bacterial species, including some undesirable spoilage bacteria and food-borne pathogens (De Vuyst \& Vandamme, 1994); the antibacterial property is heat stable, and a producer strain displays a degree of specific self-protection against its own antibacterial peptide. Bacteriocins of $\mathrm{LAB}$ are considered safe biopreservatives, as it is assumed that bacteriocins are degraded by the proteases of the gastrointestinal tract and most LAB are considered GRAS (Generally Recognized as Safe) microorganism (Holzapfel, Geisen, \& Schillinger, 1995). The only legally approved bacteriocin, for use as a preservative in a limited number of food products, from which CSS is excluded, is nisin (Delves-Broughton, Blackburn, Evans, \& Hugenholtz, 1996). 
The potential use of LAB bacteriocin-producers as biopreservatives requires good competitive properties of the added culture with the indigenous microflora in the specific product, yet not in themselves increasing the spoilage rate of the product. Furthermore, for their commercial application as protective cultures in vacuumpacked CSS, a complete understanding of the influence of the intrinsic and extrinsic conditions to be found in the food matrix on the production of bacteriocin, will be important. In this respect, bacteriocin titres can dramatically change on altering environmental conditions and optimum production may require a certain combination of influencing factors (Leal-Sánchez, JiménezDíaz, Maldonado-Barragán, Garrido-Fernández, \& Ruiz-Barba, 2002). Regarding the complexity of food environments, a better knowledge of the interactions of these factors on bacteriocin production is needed. On the other hand, the absence of pathogenicity traits, such as haemolytic activity and antibiotic resistance (Embarek, Jeppesen, \& Huss, 1994), should be demonstrated for cultures suggested for use in foods, especially in the case of antilisterial Enterococcus spp. in which the horizontal transfer of plasmids may dramatically alter the phenotypes in terms of their pathogenicity (Helgason et al., 2000).

In this work, the suitability of nine antilisterial LAB strains, previously isolated and identified from vacuumpackaged CSS, as protective cultures in vacuum-packaged CSS, were evaluated in an in vitro study: Their ability to grow and produce bacteriocin in cultures simulating the conditions of temperature, salt and anaerobic atmosphere prevailing in vacuum-packaged CSS fillets was evaluated.

The minimum inhibitory concentration (MIC) of several antibiotics as well as production of histamine and tyramine, were assessed.

The haemolytic activity of the Enterococcus strains was also determined. Additionally, the kinetics of growth of these strains and bacteriocin biosynthesis were evaluated.

\section{Materials and methods}

\section{Cultures source}

Fresh gutted farmed salmon from Norway (Salmo salar) were acquired at Matosinhos' Doca (Porto, Portugal). Salmon arrived by lorry ( $72 \mathrm{~h}$ travel) in a chilled container with the temperature controlled between $0{ }^{\circ} \mathrm{C}$ and $4{ }^{\circ} \mathrm{C}$, inside polystyrene boxes (two layers of fish between two layers of ice). The fish was transported to the ESB/UCP, in chilled conditions, and submitted to a cold-smoking process (filleted, salted, rinsed, smoked and vacuum-packaged). Packs were stored for 3 weeks at $5{ }^{\circ} \mathrm{C}$ and analysed at the beginning $\left(t_{0}\right)$ and at the end of the storage period $\left(t_{1}\right)$.

\section{Isolation of the strains}

At $t_{0}$, and $t_{1}$, three smoked fillets were cut into small pieces and mixed. Ten grams of this mix were picked randomly and homogenised in $90 \mathrm{ml}$ of sterile 1/4-strength Ringer's solution (Lab M, Bury, UK) for $2 \mathrm{~min}$ in a Stomacher 400 Lab Blender (Seward Medical, London, UK). Serial decimal dilutions in 1/4-strength Ringer's solution were prepared. Three samples were analysed at each time-interval. Total LAB were enumerated by pour-plating in nitrite actidione polymyxin (NAP) agar, $\mathrm{pH} 6.7$ (Davidson \& Cronin, 1973). At $t_{0}$ and $t_{1}, 10 \%$ of colonies overall were picked randomly from NAP plates containing 10-100 colonies. Presumptive LAB were sub-cultured in All-Purpose Tween (APT, Difco Laboratories, Detroit, USA) agar, examined for purity and characterized using Gram stain, cytochrome oxidase, and catalase tests. Organisms that were Gram-positive, cytochrome oxidase negative and catalase negative were investigated for bacteriocin production active against $L$. monocytogenes 54 (culture collection from ESB/UCP, Porto, Portugal) and L. innocua 2030c (Central Public Health Laboratory, Colindale, London, UK), a tetracycline-resistant strain, using the spot method described by Tomé, Teixeira, and Gibbs (2006).

\section{Strain identication}

Antilisterial bacteriocin producer strains (nine in all) were phenotypically and genotypically identified using the API 50 CHL kit (BioMérieux, Mercy-l'Etoile, France) and the Vitek System (BioMérieux) in the case of the coccoid strains, and by PCR amplification using genus/species specific primers, respectively.

\section{Effect of salt concentration, temperature and gas atmosphere on growth and bacteriocin production}

A $2448 \mathrm{~h}$ old culture of each of the nine bacteriocinproducing strains previously isolated from vacuum-packaged CSS and identified as Ent. faecium (three strains named ET05, ET12 and ET88), Lactobacillus curvatus (3 strains named ET06, ET30 and ET31), Lact. delbrueckii (one strain, ET32), Pediococcus acidilactici (one strain, ET34) and Lact. fermentum (one strain, ET35), was inoculated individually $(1 \% \mathrm{v} / \mathrm{v})$ into APT broth with $0.5 \%$ (standard media, control), $3 \%$ and $5 \%$ w/v salt $(\mathrm{NaCl})$ concentration. Cultures were incubated at $5{ }^{\circ} \mathrm{C}, 10^{\circ} \mathrm{C}$ and $25^{\circ} \mathrm{C}$ without agitation, under aerobic and anaerobic atmospheres for six days. At appropriate intervals, samples were taken from the cultures and analysed in duplicate for bacteriocinogenic activity using $L$. monocytogenes 54 as indicator microorganism. Antilisterial activity of cell-free culture supernatants was determined as described by Tomé et al. (2006). Antimicrobial titres were calculated by the twofold dilutions assay (Mayr-Harting, Hedges, \& Berkley, 1972). Those strains capable of growth and producing an 
active bacteriocin in conditions simulating those pertaining in vacuum-packaged CSS, were selected for the next assays.

\section{Statistical analysis}

Statistical data analysis, based on experimental design methodology, was carried out to study the effect of different variables on the time required to achieve the maximal production of bacteriocins produced by strains ET05, ET06, ET30, ET32, ET34. A full $3^{3}$ factorial design was used to gather experimental data. The factors were temperature, $\mathrm{NaCl}$ concentration and gas atmosphere. One response was analysed. i.e. time ( $\mathrm{min}$ ) required to reach the titre. Each assay was performed in duplicate in one block. Analysis of variance and effects calculations were performed using the software Statistica 6.0 (StatSoft Inc., USA) to evaluate differences of means between treatments. It was accepted there was a significant difference if $P<0.05$.

Kinetics of growth and bacteriocin biosynthesis

For these studies, $250 \mathrm{ml}$ of APT broth was inoculated with $100 \mu \mathrm{l}$ of an $18-24 \mathrm{~h}$ old culture of strains ET05, ET06, ET30, ET32 and ET34, at an initial cell concentration of $10^{5}-10^{6} \mathrm{cfu} \mathrm{ml}^{-1}$ and incubated at $30^{\circ} \mathrm{C}$ without agitation. At appropriate intervals, samples were taken for measurement of cell growth by viable plate counts in APT agar and bacteriocin production. The antibacterial activity was evaluated by assaying serial twofold dilutions of each culture filtrate supernatant fluid (CFSF) against L. monocytogenes 54 .

Haemolytic reactions

The haemolytic activity of Ent. faecium strain ET05 was determined. The enterococci were grown at $30^{\circ} \mathrm{C}$ for $12 \mathrm{~h}$ in APT medium, and then streaked onto Columbia Agar plates containing $5 \% \mathrm{v} / \mathrm{v}$ of sheep blood (BioMérieux). The plates were incubated at $37^{\circ} \mathrm{C}$ overnight. The haemolytic reactions were recorded by observation of a clear zone around the colonies ( $\beta$-haemolysis), a partial hydrolysis and greening zone ( $\alpha$-haemolysis) or no reaction ( $\gamma$-haemolysis; De Vuyst, Foulquie' Moreno, \& Revets, 2003).

Determination of the minimum inhibitory concentration (MICs) of antibiotics

MICs $\left(\mu \mathrm{ml}^{-1}\right)$ for strains Ent. faecium ET05, Lact. curvatus ET06 and ET30, Lact. delbrueckii ET32 and Ped. acidilactici ET34 were determined by the agar microdilution method on Mueller-Hinton agar medium (MHA, BioMérieux), MHA cation adjusted medium (MHCAA, BioMérieux) for penicillin $G$ and ampicillin, and Brain Heart Infusion medium (Difco) for vancomycin, in accordance with the guidelines of the National Committee for Clinical Laboratory Standards (NCCLS, 2004). Ent. faecalis ATCC 29212 and Staph. aureus ATCC 25213, were used as quality control strains following the methods described in Table 2D - Enterococcus spp. and in Table 2C - Staphylococcus spp. M7-MIC of the NCCLS guidelines (NCCLS, 2004), respectively. All the antibiotics were purchased from Sigma (Chemical Co, Germany), with the exceptions of rifampicin, tetracycline and gentamicin kindly supplied by the company Labesfal (Tondela, Portugal). One colony of each isolate with typical morphology was selected from an agar plate that had been incubated overnight, inoculated into APT broth and incubated at $37^{\circ} \mathrm{C}$ for $12 \mathrm{~h}$. The turbidity of the cellular suspensions was adjusted to approximately $0.5 \mathrm{McF}$ arland standards. Susceptibility determinations of each antibiotic were performed at least in duplicate experiments.

\section{Histamine and tyramine production}

The five strains of LAB bacteriocin-producers, mentioned previously, were screened for the detection of histidine and tyrosine decarboxylase activity, according to the methodology described by Bover-Cid and Holzapfel (1999). LAB strains were sub-cultured seven times in MRS broth (Merck, Darmstadt, Germany) with $0.1 \%$ of each precursor amino-acid (all from Sigma) in order to promote enzyme induction. Then, all strains were spotted in duplicate on the Bover-Cid medium plates with and without each amino-acid (as control) and incubated at $37^{\circ} \mathrm{C}$ for 4 days under aerobic conditions.

\section{Results}

Eec tof salt concentration, temperature and gas atmosphere on growth and bacteriocin production

The antimicrobial activities of the CFSF from bacteriocin-producing $\mathrm{LAB}$, grown for six days at three different temperatures, three salt concentrations and two atmospheric conditions, are shown in Tables 1 and 2. Although all the strains were capable of growth in the presence of $3 \%$ and $5 \% \mathrm{w} / \mathrm{v} \mathrm{NaCl}$ at $25^{\circ} \mathrm{C}, 10^{\circ} \mathrm{C}$ and $5{ }^{\circ} \mathrm{C}$, both in the presence or absence of air (results not shown), there was great variation in the antimicrobial activities of the bacteriocin-producing strains, affected by combinations of these three factors. Low temperature and high salt concentration were the most inhibitory factors affecting bacteriocin production (Tables 1 and 2).

The statistical analysis showed that low temperature $(P<0.05)$ was the main factor that negatively influenced bacteriocin production by these LAB. A reduction of the temperature retarded bacteriocin production or activity. In the cases of LAB ET05, ET06, ET30 and ET34, bacteriocin production or activity was also affected, to a lesser degree, by the gas atmosphere. The aerobic condition improved bacteriocin production/activity by the producer strains ET05, ET30 and ET34 whilst the anaerobic atmosphere was more favourable for bacteriocin production/ activity by strain ET06. No influence of the atmosphere 
Table 1

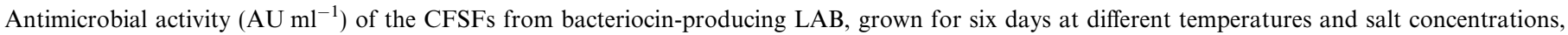
under aerobic atmosphere, against L. monocytogenes 54 (ESB/UCP, culture collection)

\begin{tabular}{|c|c|c|c|c|c|c|c|c|c|}
\hline \multirow[t]{2}{*}{ Strains } & \multicolumn{3}{|c|}{$0.5 \% \mathrm{NaCl}$} & \multicolumn{3}{|c|}{$3 \% \mathrm{NaCl}$} & \multicolumn{3}{|c|}{$5 \% \mathrm{NaCl}$} \\
\hline & $5^{\circ} \mathrm{C}$ & $10^{\circ} \mathrm{C}$ & $25^{\circ} \mathrm{C}$ & $5^{\circ} \mathrm{C}$ & $10^{\circ} \mathrm{C}$ & $25^{\circ} \mathrm{C}$ & $5^{\circ} \mathrm{C}$ & $10^{\circ} \mathrm{C}$ & $25^{\circ} \mathrm{C}$ \\
\hline ET05 & 10,000 & 10,000 & 10,000 & 10,000 & 10,000 & 10,000 & 10,000 & 10,000 & 10,000 \\
\hline ET06 & 1000 & 1000 & 1000 & 1000 & 1000 & 1000 & 800 & 800 & 800 \\
\hline ET12 & nd & nd & 800 & nd & nd & 800 & nd & nd & 800 \\
\hline ET30 & 2000 & 2000 & 2000 & 2000 & 2000 & 2000 & 2000 & 2000 & 2000 \\
\hline ET31 & 1000 & 1000 & 1000 & nd & nd & 200 & nd & nd & nd \\
\hline ET32 & 2000 & 2000 & 2000 & 2000 & 2000 & 2000 & 2000 & 2000 & 2000 \\
\hline ET34 & 1000 & 1000 & 1000 & 1000 & 1000 & 1000 & 1000 & 1000 & 1000 \\
\hline ET35 & nd & 800 & 800 & nd & 200 & 200 & nd & nd & nd \\
\hline ET88 & 400 & 400 & 1000 & nd & nd & nd & nd & nd & nd \\
\hline
\end{tabular}

nd $=$ Not detected.

Table 2

Antimicrobial activity $\left(\mathrm{AU} \mathrm{ml}{ }^{-1}\right.$ ) of the CFSFs from bacteriocin-producing $\mathrm{LAB}$, grown for six days at different temperatures and salt concentrations, under anaerobic atmosphere, against L. monocytogenes 54 (ESB/UCP, culture collection)

\begin{tabular}{|c|c|c|c|c|c|c|c|c|c|}
\hline \multirow[t]{2}{*}{ Strains } & \multicolumn{3}{|c|}{$0.5 \% \mathrm{NaCl}$} & \multicolumn{3}{|c|}{$3 \% \mathrm{NaCl}$} & \multicolumn{3}{|c|}{$5 \% \mathrm{NaCl}$} \\
\hline & $5^{\circ} \mathrm{C}$ & $10^{\circ} \mathrm{C}$ & $25^{\circ} \mathrm{C}$ & $5^{\circ} \mathrm{C}$ & $10^{\circ} \mathrm{C}$ & $25^{\circ} \mathrm{C}$ & $5^{\circ} \mathrm{C}$ & $10^{\circ} \mathrm{C}$ & $25^{\circ} \mathrm{C}$ \\
\hline ET05 & 10,000 & 10,000 & 10,000 & 10,000 & 10,000 & 10,000 & 10,000 & 10,000 & 10,000 \\
\hline ET06 & 1000 & 1000 & 1000 & 1000 & 1000 & 1000 & 1000 & 1000 & 1000 \\
\hline ET30 & 2000 & 2000 & 2000 & 2000 & 2000 & 2000 & 2000 & 2000 & 2000 \\
\hline ET31 & 1000 & 1000 & 1000 & nd & nd & 200 & nd & nd & nd \\
\hline ET32 & 2000 & 2000 & 2000 & 2000 & 2000 & 2000 & 2000 & 2000 & 2000 \\
\hline ET88 & 400 & 400 & 1000 & nd & nd & nd & nd & nd & nd \\
\hline
\end{tabular}

$\mathrm{nd}=$ Not detected.

was observed in relation to antimicrobial activity of strain ET32. The presence of $0.5 \%, 3 \%$ or $5 \% \mathrm{w} / \mathrm{v}$ of $\mathrm{NaCl}$ in the media, did not affect the response in any case. There was interaction between the factors temperature and gas atmosphere shown by statistical analyses, for antimicrobial production by LAB strains ET05, ET06, ET30 and ET34.

\section{Kinetic of growth and bacteriocin biosynthesis}

Activity of bacteriocins from Ent. faecium ET05, Lact. curvatus ET06 and Lact. curvatus ET30 was detected for the first time at the beginning of the exponential phase, at a cell count in the order of $10^{6} \mathrm{cfu} \mathrm{ml}^{-1}, 10^{8} \mathrm{cfu} \mathrm{ml}^{-1}$, and $10^{6} \mathrm{cfu} \mathrm{ml}^{-1}$, respectively (about 800 and $400 \mathrm{AU} \mathrm{ml}^{-1}$ respectively), and reached the maximum activity $(10,000$; 1000 and $2000 \mathrm{AU} \mathrm{ml}^{-1}$, respectively) between 12 and $14 \mathrm{~h}$ of incubation at $25^{\circ} \mathrm{C}$ for ET05 and $24 \mathrm{~h}$ of incubation for strains ET06 and ET30, at the stationary phase (Fig. 1a-c, respectively). Bacteriocins titres remained constant at least for $48 \mathrm{~h}$ of incubation (results not shown). Similar behaviour was observed with the growth and bacteriocin activity of Lact. delbrueckii ET32 and it Ped. acidilactici ET34 (Fig. 1d and e). Bacteriocin activity was detected, for both strains, for the first time in the log phase after $4 \mathrm{~h}$ and $6 \mathrm{~h}$ of incubation, respectively. The maximal activity was recorded in the stationary phase with a cell number in the order of $10^{8} \mathrm{cfu} \mathrm{ml}^{-1}$ and $10^{9} \mathrm{cfu} \mathrm{ml}^{-1}$, respectively. Then, the bacteriocins activity remained stable during stationary phase at $25^{\circ} \mathrm{C}$.

\section{Haemolysis reactions}

No haemolytic activity was observed for Ent. faecium strain ET05 ( $\gamma$-haemolytic).

\section{Determination of the minimum inhibitory concentration of antibiotics}

The MICs of several antibiotics for strains ET05, ET06, ET30, ET32 and ET34 were determined (Table 3). The difference in MIC results for all $\beta$-lactams, never exceeded 1 order of dilution (less for penicillin). The highest MICs for ampicillin and penicillin were $0.5 \mu \mathrm{g} \mathrm{m}^{-1}$ and $1 \mu \mathrm{g} \mathrm{ml}^{-1}$, respectively, recorded for Ent. faecium strain ET05. According to microbiological breakpoints established by NCCLS (2004) and the Scientific Committee of Animal Nutrition (SCAN, 2005), all the strains assessed showed sensitivity to these antibiotics. All strains resisted an oxacillin concentration $\geqslant 64 \mu \mathrm{g} \mathrm{ml}^{-1}$ (results not shown). All strains showed MICs $\geqslant 64 \mu \mathrm{g} \mathrm{ml}^{-1}$ for nitrofurantoin. 

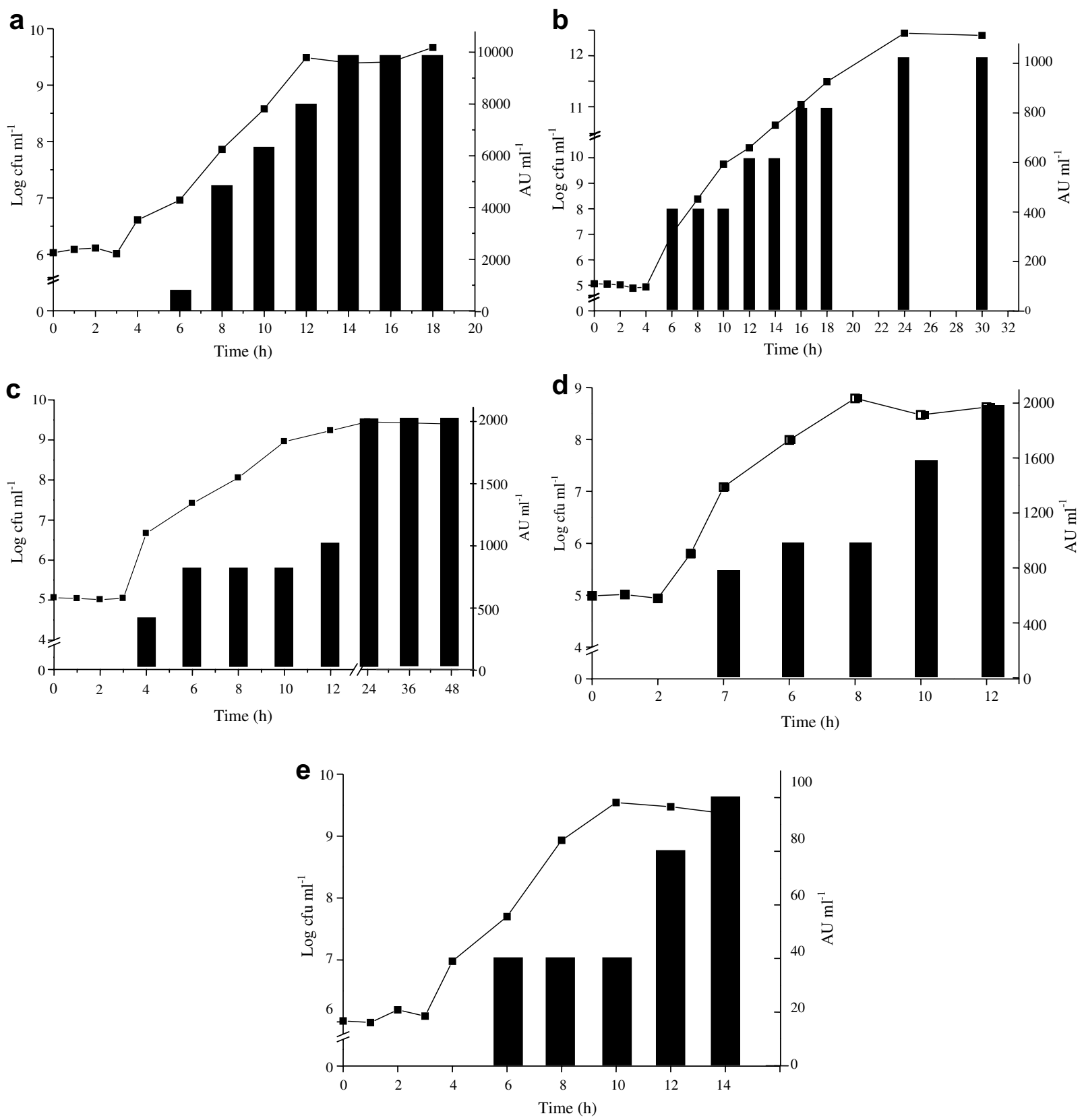

Fig. 1. Cell growth (ם) and bacteriocin production (ד) in APT broth, at $25^{\circ} \mathrm{C}$ of (a) Ent. faecium ET05; (b) Lact. curvatus ET06; (c) Lact. curvatus ET30; (d) Lact. delbrueckii E32; (e) Ped. acidilactici ET34

Table 3

Minimum inhibitory concentration (MIC; $\mu \mathrm{g} \mathrm{ml}^{-1}$ ) of several antibiotics for LAB strains ${ }^{\mathrm{a}}$ isolated from vacuum-packaged CSS fillets

\begin{tabular}{|c|c|c|c|c|c|c|c|c|c|}
\hline Strains & Ampicillin & Penicillin G & Erythromycin & Vancomycin & Chloramphenicol & Tetracycline & Rifampicin & Gentamicin & Nitrofurantoin \\
\hline ET05 & 0.5 & 1 & 8 & 2 & 32 & 1 & 0.5 & 8 & 128 \\
\hline ET06 & 0.25 & 0.125 & 16 & 32 & 8 & 0.25 & 0.0625 & 64 & 64 \\
\hline ET30 & 0.25 & 0.25 & 4 & 8 & 8 & 1 & 0.0625 & 64 & 64 \\
\hline ET32 & 0.25 & 0.25 & 4 & 64 & 8 & 32 & 0.5 & 0.5 & 128 \\
\hline ET34 & 0.25 & 0.25 & 4 & 32 & 16 & 8 & 0.5 & 0.5 & 128 \\
\hline
\end{tabular}

${ }^{a}$ ET05: Ent. faecium; ET06: Lact. curvatus; ET30: Lact. curvatus; ET32: Lact. delbrueckii; ET34: Ped. acidilactici.

According to the MIC proposed by NCCLS (2004) for Enterococcus spp., strain ET05 was sensitive to this antibi- otic. There is no breakpoint value suggested by the SCAN (2005) for this antibiotic. The vancomycin MIC value for 
Ent. faecium strain ET05 was $2 \mu \mathrm{g} \mathrm{ml}^{-1}$, indicating sensitivity of this strain to this antibiotic. There are no breakpoints established for vancomycin with respect to heterofermentative lactobacilli, like Lact. curvatus strains (ET06 and ET30). Lact. delbrueckii, obligately homofermentative (Hammes \& Vogel, 1995), was resistant to this antibiotic, exhibiting the highest MIC for vancomycin $\left(64 \mu \mathrm{g} \mathrm{ml}^{-1}\right.$, respectively) whilst $\mathrm{MIC}$ for Ped. acidilactici was not required according to SCAN (2005). The MICs of erythromycin affected the synthesis of proteins of Ent. faecium ET05 (according to NCCLS, 2004), Lact. curvatus ET30, Lact. delbrueckii ET32 and Ped. acidilactici E T34, whilst Lact. curvatus ET06 was resistant to this antibiotic. All strains were resistant to chloramphenicol, with MICs higher than the microbiological breakpoints suggested by SCAN (2005); the NCCLS (2004) has established breakpoints for this antibiotic only for the enterococci, in which case the assessed strain ET05 would be sensitive. Most of the strains were susceptible to tetracycline although Lact. delbrueckii and Ped. acidilactici were strongly resistant strains with MICs of $32 \mu \mathrm{g} \mathrm{ml}^{-1}$ and $8 \mu \mathrm{g} \mathrm{ml}^{-1}$, respectively. Lact. curvatus ET06 and ET30 strains showed a strong resistance to the aminoglycoside gentamicin, whilst a low concentration of gentamicin affected Ent. faecium ET05, Lact. delbrueckii ET32 and Ped. acidilactici ET34. The breakpoints for rifampicin have been established by NCCLS (2004) only for Enterococcus strains, strain ET05 is sensitive to this antibiotic. All the other strains were susceptible to low levels of rifampicin $\left(\leqslant 0.5 \mu \mathrm{g} \mathrm{ml}^{-1}\right)$.

\section{Histamine and tyramine determination}

None of the strains assessed were histamine-producers, although Ent. faecium ET05, Lact. curvatus ET06 and Lact. curvatus ET30 did decarboxylate tyrosine to form tyramine.

\section{Discussion}

Eect of salt concentration, temperature and gas atmosphere on growth and bacteriocin production

The lack of or the low activity levels recorded for bacteriocin producers ET12, ET31, ET35 and ET88 at high salt concentration (up 5\%), at refrigeration temperatures $\left(5^{\circ} \mathrm{C}\right.$ and $10^{\circ} \mathrm{C}$ ) both in aerobic and anaerobic atmospheres after six days of growth (Tables 1 and 2), despite relatively good cell growth, suggests an antagonistic effect of these three factors when combined ('hurdle effect' on inhibitor production). This may indicate an important constraint in the potential use of these strains as antilisterial factors in salted products like vacuum-packed CSS fillets. Similar detrimental effects of high concentrations of $\mathrm{NaCl}$, have been reported by Verluyten, Messens, and De Vuyst (2004). Some authors comment that growth of LAB in environments with high salt concentrations $(\mathrm{NaCl}$ concentrations higher than $3 \%$ ), is inhibited, whilst lower amounts from $1 \%$ to $2 \%$ can exert a positive effect (Gänzle, Ehrmann, \& Hammes, 1998; Korkeala, Alanko, \& Tiusanen, 1992). Accord ing to Neysen, Messens, and De Vuyst (2003), amylovorin L471 production by Lact. amylovorus DCE 471 was negatively affected by $\mathrm{NaCl}$, because the amount of biomass formed was lower. Most Ent. faecium and Pediococcus species are facultatively anaerobic cocci with the ability to grow in broth containing $6.5 \% \mathrm{NaCl}$, at $10{ }^{\circ} \mathrm{C}$. However, among the strains of Ent. faecium studied, only ET05 was able to yield an active bacteriocin at higher salt concentrations, both at $5{ }^{\circ} \mathrm{C}$ and $10^{\circ} \mathrm{C}$. Homofermentative microorganisms like Lact. delbrueckii are in general more salt tolerant than heterofermentative LAB; Korkeala et al. (1992) have reported enhanced growth of some homofermentative LAB after supplementing media with high salt concentrations. Lact. curvatus and Lact. delbrueckii cultures have also been isolated from vacuumpacked trout and salmon by González-Rodríguez, Sanz, Santos, Otero, and García-López (2002) as well as the former organism from vacuum-packed me at (De Martinis, Santarosa, \& Freitas, 2003). Therefore the growth of these LAB at salt concentrations up to $5 \%$, at low temperatures both in aerobic and anaerobic atmosphere, was expected. According to the statistical analyses, higher temperatures as well as aerobic atmosphere are the most favourable conditions for the production of most of the bacteriocins in this study, whilst low temperatures and anaerobic atmosphere increase the time required for bacteriocin production, with the exception of bacteriocin ET06, for which bacteriocin production was encouraged under anaerobic atmosphere. These results are in agreement with those of Aymerich, Artigas, Garriga, Monfort, and Hugas (2000), who reported that production of enterocins in vitro by Ent. faecium CTC492 was decreased at lower temperatures. However, Jeppesen and Huss (1993) studying the antagonistic activity of LAB isolated from chilled fish products, observed that lowering the temperature from $25^{\circ} \mathrm{C}$ to $5^{\circ} \mathrm{C}$ in some cases increased and in other cases, decreased the antagonistic effect. This unpredictable effect was explained by the fact that not only the inhibitory strain is affected, but also the test organism, resulting in altered microbial interactions. The temperature dependency of the pediocin-like bacteriocins is related with the C-terminal disulfide bridge (Fimland et al., 2000). In relation to bacteriocin production, most of the literature indicates that the production/activity of class II bacteriocins is pH-dependent as a result of different adsorption characteristics. For instance enterocin production was maximal at neutral $\mathrm{pH}$ according to the results of Parente and Ricciardi (1994). The production of enterocin in vitro was inhibited below pH 5.5 (Aymerich et al., 2000). The five LAB bacteriocin-producers in the current study, reached their maximum titre at the stationary phase with a high cell concentration in the growth media (results not shown). It is probable that in these "stress conditions" (low $\mathrm{pH}$ ) the time required to reach the stationary phase was longer and obviously the bacteriocin production/activity lower. In 
this situation, the change in the $\mathrm{pH}$ response for bacteriocin activity would be affected.

Thinking of the potential use of these strains as protective cultures in vacuum-packed CSS, although the combination of refrigeration temperature and anaerobic atmosphere was unfavourable for bacteriocin production/ activity, in the worst situation, the maximum time required to achieve the maximum titre at $5{ }^{\circ} \mathrm{C}, 5 \% \mathrm{NaCl}$ and anaerobic atmosphere was: 5 days for bacteriocin ET05, 3 days for bacteriocin ET06, 4.5 days for bacteriocins ET30 and ET34, and 6 days for bacteriocin ET32. However, only a few hours were sufficient to attain inhibitory activity values able to suppress $L$. monocytogenes growth, then increasing rapidly until achieving the maximum titre.

\section{Kinetics of growth and bacteriocin biosynthesis}

In kinetic studies, like production of most bacteriocins (González, Arca, Mayo, \& Suárez, 1994; Pilet et al., 1995; Rattanachaikunsopon \& Plumkhachom, 2000), the bacteriocins of LAB in this study were secreted into the culture medium in the early exponential phase of growth, with increasing production during this phase, reaching their maximum concentrations at the stationary phase. The inhibitory activity remained stable when the cells entered the stationary phase suggesting that the bacteriocin was unaffected by prolonged incubation under strongly acidic conditions. These results suggest that these bacteriocins may not be essential for the growth of, or successful competition by these strains in mixed culture systems (as occur in foods). Therefore, it is likely that the bacteriocins of current interest are secondary metabolites. In contrast with other bacteriocins, their production in APT broth was not dependent on reaching the stationary growth phase (Enan, El-Essawy, Uyttendaele, \& Debevere, 1996). Similarly, bacteriocins production by Carnobacterium divergens and C. piscicola (Pilet et al., 1995), Ped. acidilactici (NietoLozano, Reguera-Useros, Pelaez-Martínez, \& De la Torre, 2002), and bacteriocin ST15 produced by Ent. mundtii (De Kwaadsteniet, Todorov, Knoetze, \& Dicks, 2005), was related to entry into the stationary phase.

\section{Haemolysis and antibiotic susceptibility test}

The emergence and dissemination of resistant bacteria and resistance genes in microbial populations in animals and humans, where antibiotics are used for therapy and prophylaxis of infectious diseases (Van den Bogaard \& Stobberingh, 2000) is a world-wide problem. An important drawback of antibiotic resistance is the possibility for transfer of genes controlling antibiotic resistance. As these genes are generally carried on plasmids, they can be transferred to other bacteria mainly by conjugation, Although LAB themselves are generally considered non-pathogenic they can transfer antibiotic resistance genes to pathogenic bacteria that infect humans or animals. Therefore, before LAB strains can be used as an additive they must undergo antibiotic resistance screening.Enterococci strains have been involved in infections, and various strains have shown antibiotic resistance traits (Jett, Huycke, \& Gilmore, 1994; Morrison, Woodford, \& Cookson, 1997). Therefore, antibiotic resistance, at least to vancomycin, and the presence of haemolysins as an indicator of potential pathogenicity, must be evaluated in these microorganisms, before they can be used as food additives.

Cytolysin/haemolysin activity is seen to be a potent virulence factor in several animal model studies (Chow et al., 1993), and it plays an important role in the severity of human infections (Jett et al., 1994). Cytolysin expression goes hand-in-hand with haemolysis. In $\beta$-haemolytic Ent. faecalis strains the cytolysin structural gene was always present, whilst in Ent. faecium this gene could not be detected (De Vuyst et al., 2003) and haemolysis by the latter species must be caused by another cytotoxic component. In general, the incidence of $\beta$-haemolysis is lower in Ent. faecium strains than in Ent. faecalis strains. In this study no haemolytic activity was observed for Enterococcus strains; however, absence of haemolytic activity does not necessarily mean that these bacteria are non-virulent (Franz et al., 1999). Among the antibiotic resistance patterns, vancomycin resistance is of major concern because vancomycin is one of the last antibiotics broadly efficacious against clinical infections caused by multidrug-resistant pathogens (Woodford, Johnson, Morrison, \& Speller, 1995). Moreover, vancomycin resistance is encoded by transferable genetic elements (Arthur \& Courvalin, 1993). Regarding this point, only Lact. delbrueckii ET32 was resistant to vancomycin. However, Hamilton-Miller and Shah (1998) pointed out that pediococci have a high innate resistance to Vancomycin, also to gentamicin and nitrofurantoin, a property that is useful to separate them from other Gram-positive bacteria. None of the LAB strains isolated from vacuum-packaged CSS showed resistance to ampicillin or penicillin. In this respect, Butaye et al. (2000) found that among E. faecium strains isolated from several raw and processed foods, resistance to growth promoting antibacterials used in animals, and antibiotics used therapeutically in humans, was rare. In another study (Lopes, Ribeiro, Martins, Tenreiro, \& Barreto, 2003), among enterococci isolated from Portuguese dairy products, a high level of gentamicin resistance was detected in many isolates. Although enterococci are generally regarded as being intrinsically resistant to low levels of gentamicin, E. faecium ET05 as well as Ped. acidilactici ET34 and Lact. delbrueckii ET32 were sensitive to this antibiotic, whilst Lact. curvatus (ET06 and ET30) strains were resistant. An overview of antibiotic resistances associated with LAB in fermented dry sausage (Mathur \& Singh, 2005) registered $79 \%$ for gentamicin and $64 \%$ for penicillin G. From this data and those cited previously, it is clear that intergenus and inter-species differences exist, and consequently identification at species level is required in order to interpret phenotypic susceptibility data. Lact. delbrueckii ET32 and Ped. acidilactici ET34 were resistant to 
tetracycline. In a study undertaken by Danielsen and Wind (2003) susceptibilities to tetracycline and ciprofloxacin varied several-fold between species. There is no information on the breakpoints for ciprofloxacin and oxacillin. As resistance to some antibiotics was observed in the LAB assessed in the present study, it would be necessary to determine whether that resistance could be transferred to other bacteria by means of conjugation, in order to avoid producing potentially pathogenic antibiotic-resistant strains in foods.

\section{Histamine and tyramine production}

Biogenic amines have been used as chemical indicators of seafood quality especially in vacuum-packaged CSS as they are associated mainly with Enterobacteriaceae strains, although some lactobacilli have also been identified as active amine producers (Jørgensen, Dalgaard, \& Huss, 2000a; Jørgensen, Huss, \& Dalgaard, 2000b). Biogenic amines generated by bacterial decarboxylation of aminoacids are involved in this process. For this reason, high temperatures (abuse) and $\mathrm{pH}$ values favourable to bacterial growth accelerate the production of these compounds. Free histidine, the substrate for histamine production, can be found in sufficient concentration in salmon flesh to allow such production, and high levels of histamine have been found in routine control of smoked salmon in Denmark (Huss, Ben Embarek, \& Jeppesen, 1995). None of the isolates from vacuum-packaged CSS that were assessed were able to produce histamine, which is regarded as the main agent for scombroid fish poisoning (Taylor, 1986). However, Ent. faecium ET05, Lact. curvatus ET06 and Lact. curvatus ET30 produced tyramine. Our results regarding the ability to produce tyramine by $\mathrm{LAB}$, are in agreement with the major percentages of LAB tyramine-producers recorded by Bover-Cid and Holzapfel (1999). According to Jørgensen et al. (2000a, 2000b), Lact. curvatus frequently dominates the LAB colonizing lightly preserved fish products, and was identified as a specific spoilage microorganism of CSS because of its production of biogenic amines.

A wide range of levels of tyramine production were reported by Masson, Talon, and Montel (1996) in the genera Lactobacillus and Pediococcus and was highest with Lact. Curvatus, three strains out of seven producing 700 $2311 \mu \mathrm{g} \mathrm{ml}^{-1}$. In a study by Petäjä, Eerola, and Petäjä (2000) to examine formation of biogenic amines during the fish fermentation process, using LAB as starter cultures (Ped. acidilactici and Lact. sakei), formation of biogenic amines was reduced by inhibiting the growth and activity of both proteolytic and decarboxylating microorganisms. Whilst tyramine may cause migraine headaches and hypertensive effects, and in some cases can potentiate histamine effects (Ten Brink, Damink, Joosten, \& Huis, 1990), no legal upper limit exists for tyramine in fish products in European legislation, and tyramine has never been associated with fish poisoning in contrast to histamine.
From the results obtained in the current research, Ent. faecium ET05, Lact. curvatus ET06 and ET30, Lact. delbrueckii ET32 and Ped. acidilactici ET34, seem to possess the attributes necessary for a successful test in salmon fillets cold-smoked processed, packed under vacuum and stored at refrigerator temperature. Additionally, other positive features of these five LAB include their sensitivity to vancomycin and their inability to produce histamine from the amino-acid histidine, and their lack of haemolytic activity ( $\gamma$-haemolysis) by Ent. faecium strain ET05. However in vivo experiments must be designed to study what levels of these microorganisms are compatible with organoleptic qualities of CSS.

\section{Acknowledgements}

Financial support to author Tomé was provided by a $\mathrm{PhD}$ fellowship issued by Consejo de Desarrollo Científico y Humanístico de la Universidad Central de Venezuela.

\section{References}

Arthur, M., \& Courvalin, P. (1993). Genetics and mechanisms of glycopeptide resistance in enterococci. Antimicrobial Agents and Chemotherapy, 37, 1563-1571.

Aymerich, T., Artigas, M. G., Garriga, M., Monfort, J. M., \& Hugas, M. (2000). Effect of sausage ingredients and additives on the production of enterocins A and B by Enterococcus faecium CTC492. Optimization of in vitro production and anti-listerial effect in dry fermented sausages. Journal of Applied Microbiology, 88, 686-894.

Bover-Cid, S., \& Holzapfel, W. H. (1999). Improved screening procedure for biogenic amine production by lactic acid bacteria. International Journal of Food Microbiology, 53, 33-41.

Butaye, P., van Damme, K., Devriese, L. A., van Damme, L., Bael, M., Lauwers, S., et al. (2000). In vitro susceptibility of Enterococcus faecium isolated from food to growth-promoting and therapeutic antibiotics. International Journal of Food Microbiology, 54, 181-187.

Chow, J. W., Thal, L. A., Perri, M. B., Vazquez, J. A., Donabedian, S. M., Clewell, D. B., et al. (1993). Plasmid-associated hemolysin and aggregation substance production contribute to virulence in experimental enterococcal endocarditis. Antimicrobial Agents and Chemotherapy, 37, 2474-2477.

Danielsen, M., \& Wind, A. (2003). Susceptibility of Lactobacillus spp. to antimicrobial agents. International Journal of Food Microbiology, $82(1), 1-11$.

Davidson, C., \& Cronin, F. (1973). Medium for the selective enumeration of lactic acid bacteria from foods. Journal of Applied Microbiology, 26, 439-440.

De Kwaadsteniet, S. D., Todorov, S. D., Knoetze, H., \& Dicks, L. M. T. (2005). Characterization of a 3944 Da Bacteriocin, produced by Enterococcus mundtii ST15, with activity against Gram-positive and Gram-negative bacteria. International Journal of Food Microbiology, $105,433-444$.

De Martinis, E. C. P., Santarosa, P. R., \& Freitas, F. (2003). Caracterização preliminar de bacteriocinas produzidas por seis cepas de bactérias láticas isoladas de produtos cárneos embalados a vácuo. Ciência y Tecnología Alimentaria, 23(2), 195-199.

De Vuyst, L., Foulquie' Moreno, M. R., \& Revets, H. (2003). Screening for enterocins and detection of hemolysin and vancomycin resistance in enterococci of different origins. International Journal of Food Microbiology, 84, 299-318.

De Vuyst, L., \& Vandamme, E. J. (1994). Antimicrobial potential of lactic acid bacteria. In L. De Vuyst \& E. J. Vandamme (Eds.), Bacteriocins of lactic acid bacteria (pp. 91-142). London: Chapman and Hall. 
Delves-Broughton, J., Blackburn, P., Evans, R. J., \& Hugenholtz, J. (1996). Applications of the bacteriocin, nisin. Antonie Van Leeuwenhoek, 69, 193-202.

Embarek, P. K., Jeppesen, V. F., \& Huss, H. H. (1994). Antibacterial potential of Enterococcus faecium strains to inhibit Clostridium botulinum in sous-vide cooked fish fillets. Food Microbiology, 11, $525-536$.

Enan, G., El-Essawy, A. A., Uyttendaele, M., \& Debevere, J. (1996). Antibacterial activity of Lactobacillus plantarum UG1 isolated from dry sausage: characterization, production and bactericidal action of plantaracin UG1. International Journal of Food Microbiology, 30, $189-215$.

Fimland, G., Johnsen, L., Axelsson, L., Brurberg, M. B., Nes, I. F., Eijsink, V. G., et al. (2000). A C-terminal disulfide bridge in pediocinlike bacteriocins renders bacteriocin activity less temperature dependent and is a major determinant of the antimicrobial spectrum. Journal of Bacteriology, 182(9), 2643-2648.

Franz, C. M., Worobo, R. W., Quadri, L. E., Schillinger, U., Holzapfel, W. H., Vederas, J. C., et al. (1999). Atypical genetic locus associated with constitutive production of enterocin B by Enterococcus faecium BFE900. Applied and Environmental Microbiology, 65, 2170-2178.

Gänzle, M. G., Ehrmann, M., \& Hammes, W. P. (1998). Modeling of growth of Lactobacillus sanfranciscensis and Candida milleri in response to process parameters of sourdoughs fermentation. Applied and Environmental Microbiology, 64, 2616-2623.

González, B., Arca, P., Mayo, B., \& Suárez, J. E. (1994). Detection, purification and partial characterization of plantaricin $\mathrm{C}$ a bacteriocin produced by a Lactobacillus plantarum strain of dairy origin. Applied and Environmental Microbiology, 60, 2158-2163.

González-Rodríguez, M. N., Sanz, J. J., Santos, J. A., Otero, A., \& García-López, M. L. (2002). Numbers and types of microorganisms in vacuum-packed cold-smoked freshwater fish at the retail level. International Journal of Food Microbiology, 77, 161-168.

Hamilton-Miller, J. M. T., \& Shah, S. (1998). Vancomycin susceptibility as an aid to the identification of lactobacilli. Letters in Applied Microbiology, 26(2), 153-154.

Hammes, W. P., \& Vogel, R. F. (1995). The genus Lactobacillus. In B. J. B. Wood \& W. H. Holzapfel (Eds.), The genera of lactic acid bacteria (pp. 9-54). London: Elsevier Applied Science Publishers.

Helgason, E., Andreas, O., Caugant, A., Henning, A., Fouet, A., Mock, M., et al. (2000). Bacillus anthracis, Bacillus cereus and Bacillus thuringiensis-one species on the basis of genetic evidence. Applied and Environmental Microbiology, 66, 2627-2630.

Henitz, M. L., \& Johnson, J. M. (1998). The incidence of Listeria spp. Salmonella spp. and Clostridium botulinum in smoked fish and shellfish Journal of Food Protection, 61(3), 318-323.

Holzapfel, W. H., Geisen, R., \& Schillinger, U. (1995). Biological preservation of foods with reference to protective cultures, bacteriocins, and food-grade enzymes. International Journal of Food Microbiology, 24, 343-362.

Huss, H. H., Ben Embarek, P. K., \& Jeppesen, V. (1995). Control of biological hazards in cold-smoked salmon production. Food Control, 6 , 335-340.

Jeppesen, V. F., \& Huss, H. H. (1993). Characteristics and antagonistic activity of lactic acid bacteria isolated from chilled fish products. International Journal of Food Microbiology, 18, 306-320.

Jett, B. D., Huycke, M. M., \& Gilmore, M. S. (1994). Virulence of enterococci. Clinical Microbiology Reviews, 7, 462-478.

Jørgensen, L. V., Dalgaard, P., \& Huss, H. H. (2000a). Multiple compound quality index for cold-smoked salmon (Salmo salar) developed by multivariate regression of biogenic amines and $\mathrm{pH}$. Journal of Agricultural and Food Chemistry, 48, 2448-2453.

Jørgensen, L. V., Huss, H. H., \& Dalgaard, P. (2000b). The effect of biogenic amine production by single bacterial cultures and metabiosis on cold-smoked salmon. Journal of Applied Microbiology, 89, 920-934.

Korkeala, H., Alanko, T., \& Tiusanen, T. (1992). Effect of sodium nitrate and sodium chloride on growth of lactic acid bacteria. Acta Veterinaria Scandinávica, 33, 27-32.
Leal-Sánchez, M. V., Jiménez-Díaz, R., Maldonado-Barragán, A., Garrido-Fernández, A., \& Ruiz-Barba, J. L. (2002). Optimization of bacteriocin production by batch fermentation of Lactobacillus plantarum LPCO10. Applied and Environmental Microbiology, 68, 4465-4471.

Lopes, M., Ribeiro, T., Martins, M. P., Tenreiro, R., \& Barreto, M. T. (2003). Gentamicin resistance in dairy and clinical enterococcal isolates and in reference strains. Journal of Antimicrobial Chemotherapy, 52, 214-219.

Masson, F., Talon, R., \& Montel, M. C. (1996). Histamine and tyramine production by bacteria from meat products. International Journal of Food Microbiology, 32, 199-207.

Mathur, S., \& Singh, R. (2005). Antibiotic resistance in food lactic acid bacteria - A review. International Journal of Food Microbiology, 105(3), 281-295.

Mayr-Harting, A., Hedges, A. J., \& Berkley, R. W. (1972). Methods for studying bacteriocins. In J. R. Norris \& D. W. Ribbons (Eds.), Methods in microbiology (pp. 16-422). New York: Academic Press Inc.

Morrison, D., Woodford, N., \& Cookson, B. (1997). Enterococci as emerging pathogens of humans. Journal of Applied Microbiology (Supplement), 83, 89S-99S.

[NCCLS] The National Committee for Clinical Laboratory Standards (2004). Performance Standards for Antimicrobial susceptibility testing; 14th informational supplement. M100-S14. Vol. 24, 1, 155 p.

Neysen, P., Messens, W., \& De Vuyst, L. (2003). Effect of sodium chloride on growth and bacteriocin production by Lactobacillus amylovorus DCE 471. International Journal of Food Microbiology, 88, 29-39.

Nieto-Lozano, J. C., Reguera-Useros, J. I., Pelaez-Martínez, M. C., \& De la Torre, A. H. (2002). Bacteriocinogenic activity from starter culture used in Spanish meat industry. Meat Science, 62, 237-243.

Parente, E., \& Ricciardi, A. (1994). Influence of $\mathrm{pH}$ on the production of enterocin 1146 during batch fermentation. Letters in Applied Microbiology, 19, 12-15.

Petäjä, E., Eerola, S., \& Petäjä, P. (2000). Biogenic amines in cold-smoked fish fermented with lactic acid bacteria. European Food Research and Technology, 210, 280-285.

Pilet, M. F., Dousset, X., Barré, R., Novel, G., Desmazeaud, M., \& Piard, J. C. (1995). Evidence for two bacteriocins produced by Carnobacterium piscicola and Carnobacterium divergens isolated from fish and active against Listeria monocytogenes. Journal of Food Protection, $58(3), 256-262$.

Rattanachaikunsopon, P., \& Plumkhachom, P. (2000). A bacteriocin produced by Lactococcus lactis subsp. lactis isolated from Thai fermented foods. Science Asia, 6, 195-200.

Scientific Committee on Animal Nutrition (SCAN; 2005). Opinion of the Scientific Committee on animal nutrition on the criteria for assessing the safety of micro-organisms resistant to antibiotics of human clinical and veterinary importance (Question $\mathrm{N}^{\circ}$ EFSA-Q-2004-079). The EFSA Journal, 223, 1-12.

Taylor, S. L. (1986). Histamine food poisoning: Toxicology and clinical aspects. Critical Reviews in Toxicology, 17, 91-128.

Ten Brink, B., Damink, C., Joosten, H. M., \& Huis, J. H. (1990). Occurrence and formation of biologically active amines in food. International Journal of Food Microbiology, 11, 73-84.

Tomé, E., Teixeira, P., \& Gibbs, P. A. (2006). Anti-listerial inhibitory lactic acid bacteria isolated from commercial cold smoked salmon. Food Microbiology, 23, 399-405.

Van den Bogaard, A. E., \& Stobberingh, E. E. (2000). Epidemiology of resistance to antibiotics - Links between animals and humans. International Journal of Antimicrobial Agents, 14, 327-335.

Verluyten, J., Messens, W., \& De Vuyst, L. (2004). Sodium chloride reduces production of curvacin A, a bacteriocin produced by Lactobacillus curvatus strain LTH 1174, originating from fermented sausage. Applied and Environmental Microbiology, 70(4), 2271-2278.

Woodford, N., Johnson, A. P., Morrison, D., \& Speller, D. C. E. (1995). Current perspective on glycopeptide resistance. Clinical Microbiology Reviews, 8, 585-615. 